\title{
Worlds apart: language survival and language use in two Middle Sepik communities
}

Des mondes à part: survie et usage du langage dans deux communautés du Moyen Sepik

\section{Alexandra Y. Aikhenvald}

\section{(2) OpenEdition}

\section{Journals}

Electronic version

URL: http://journals.openedition.org/jso/8148

DOI: $10.4000 /$ jso.8148

ISSN: $1760-7256$

\section{Publisher}

Société des océanistes

\section{Printed version}

Date of publication: 15 July 2018

Number of pages: $203-212$

ISBN: 978-2-85430-135-9

ISSN: 0300-953x

\section{Electronic reference}

Alexandra Y. Aikhenvald, « Worlds apart: language survival and language use in two Middle Sepik communities », Journal de la Société des Océanistes [Online], 146 | 2018, Online since 15 July 2020 connection on 10 December 2020. URL : http://journals.openedition.org/jso/8148 ; DOI : https:// doi.org/10.4000/jso.8148

\section{cc) (†)}

Journal de la société des océanistes est mis à disposition selon les termes de la Licence Creative Commons Attribution - Pas d'Utilisation Commerciale - Pas de Modification 4.0 International. 


\title{
Worlds apart: language survival and language use in two Middle Sepik communities
}

by

\author{
Alexandra Y. AIKHENVALD*
}

\begin{abstract}
This contribution focuses on the language situation in two different communities of the Middle Sepik area, speaking closely related languages of the Ndu family - the Manambu and the Yalaku. The two groups maintain traditional features typical of "river-dwellers" who live on the banks of the Sepik River (the Manambu) and those who live off the River, or "jungle-dwellers" (the Yalaku), including subsistence and exchange patterns. Due to a history of interactions with the Kwoma-speaking people, the Yalaku language has incorporated numerous borrowings and grammatical calques from Kwoma (not genetically related to the Ndu family to which both Manambu and Yalaku belong). In contrast, there is hardly any Manambu-Kwoma multilingualism. A major difference between the two groups lies in the high number of loans from Tok Pisin in Manambu and the scarcity of them in Yalaku. The paper addresses the changes in the lifestyles of the two groups, contrasting their responses to social and cultural changes as reflected in linguistic change and in attitudes to language.
\end{abstract}

KeYwords: Middle Sepik, Ndu language family, multilingualism, loans, Tok Pisin, language change

\section{Background: the Sepik River Basin}

From a linguistic perspective, the Sepik River Basin - which includes East Sepik and Sandaun Provinces - is one of the most complex regions within New Guinea. It is home to about two hundred distinct languages, grouped into at least ten families, in addition to dozens of isolates. Such linguistic density is apparently unparalleled elsewhere in the world. Geographical features of the region - such as mountains, waterways and swamps -,

\section{RÉSUMÉ}

Le présent article examine la situation linguistique de deux communautés du Moyen-Sepik où sont parlées des langues qui sont étroitement reliées à la famille linguistique Ndu - le manambu et le yalaku. Ces deux groupes maintiennent une culture traditionnelle typique des riverains du fleuve Sepik et de ceux qui résident dans la jungle, y compris le mode de subsistance et l'échange de produits de pêche avec le sagou. La langue yalaku a été influencée par la langue kwoma en raison d'une longue histoire dinteractions entre ces deux groupes (dont les langues ne sont pas génétiquement reliées), contrairement au manambu où l'influence de la langue kwoma est restée minime. En revanche, le manambu moderne contient de nombreux emprunts du Tok Pisin (la lingua franca de la Paponasie Nouvelle-Guinée). Cet article aborde les changements socio-culturels récents des Manambu et des Yalaku à travers une analyse de phénomènes linguistiques.

Mots-Clés : Moyen Sepik, famille linguistique Ndu, multilinguisme, emprunts, changements linguistiques, Tok Pisin

* Language and Culture Research Centre, James Cook University Australia, alexandra.aikhenvald@jcu.edu.au

differences in means of subsistence, and patterns of contact between groups are often cited as possible reasons for its linguistic and cultural diversification (see the discussion by Foley, 1986: 22-28, 1988: 167-168; Aikhenvald, 2004: 97-98; 2009). The aim of this paper is to show how linguistic and cultural differences between people with markedly different lifestyles are kept alive within the context of the Middle Sepik River Basin.

I focus on two groups who live next to each other and speak closely related languages, but drastically 


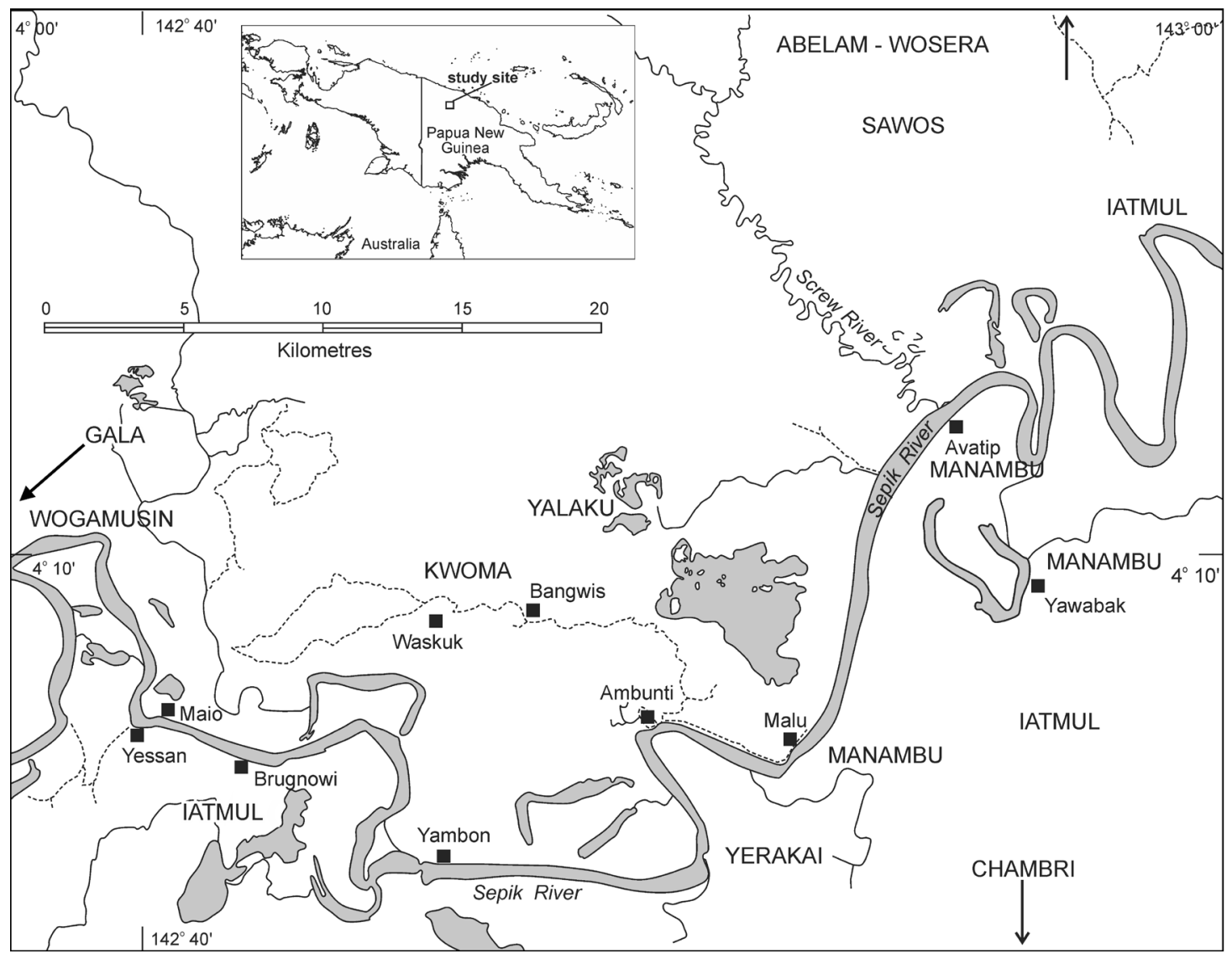

MAP 1. - The Manambu and the Yalaku speaking villages in the Ambunti region, East Sepik Province, PNG (C) Alexandra Aikhenvald)

differ from each other in terms of their traditional habitat, means of subsistence, and patterns of language contact. One group are the Manambu, who live in five villages along the Sepik River and number about 3,000 people. The other one are the Yalaku, with c. 900 people altogether, residing in three villages in the mountainous area off the Sepik River. Both are located in the Ambunti region of the East Sepik Province (see map 1). Both Manambu and Yalaku languages belong to the $\mathrm{Ndu}$ language family, a well-established linguistic family within the Sepik region and the largest one in the area in terms of number of speakers.

\section{The Ndu language family}

Unlike most other linguistic families in the region, the Ndu family is discontinuous. It stretches from the northern coast to the banks of the Sepik River and swampy off-river lowland and mountainous areas. In addition to Manambu and Yalaku, the Ndu family includes Iatmul, a dialect continuum spoken by thirty to forty thousand people along and off the Sepik river south-west of Wewak in the Ambunti and Angoram districts of the East Sepik Province (see Jendraschek, 2012);
Abelam-Wosera, a dialect continuum with over forty thousand speakers in the Maprik District of the East Sepik Province (see Wendel, 1993; Wilson, 1976); Boiken, spoken by over thirty thousand people in the Yangoru district of the East Sepik Province (including the coast and Mushu Island: see Freudenburg, 1976); Gala (previously known as Ngala), spoken by about 150 people in Swakap (or Swagup) near the junction of the Sepik River and the April River. The name Gala is preferred by the speakers of the language (as ascertained by the author during a brief expedition in October 2004), since the language does not have prenasalised word-initial stops (in contrast to Manambu and numerous other languages of the family). The status of the "Sawos" varieties as a dialect of Iatmul or as a separate language requires further study. A detailed overview of the family is in Aikhenvald (2008: 20-24, 590-5; 2009: 11-12).

Linguistic differences within the family may be partly accounted for by impact of other, unrelated languages. In Sapir's (1929: 209) words,

"no two languages are ever sufficiently similar to be considered as representing the same social reality." 
Manambu and Yalaku are closely related, and belong to the same subgroup within the Ndu family (see Aikhenvald, 2015). They are not mutually intelligible. The ways in which their speakers live differ in a number of ways, and their different social realities are reflected in their languages.

\section{The peoples of the Middle Sepik}

In terms of their subsistence, lifestyle and patterns of relationships with their neighbours, the peoples of the Middle Sepik can be roughly divided into two sets - those who live on the Sepik River - or River dwellers - and those who live off the River, on small streams, lakes and neighbouring hills. Here, as in my previous work, I use the term "Jungle dwellers" as an approximate denomination for the latter. (An alternative, "water-people" and "bush-people", was suggested by Staalsen, 1965, based on his work with the Iatmul; see also Schindlbeck, 1980 and Gewertz, 1983: 17-36, for additional differences between these two loosely defined divisions of peoples, and Aikhenvald, 2009: 13-14 for a more general approach to the relevance of this distinction in New Guinea and beyond).

Members of the Ndu family include both River dwellers who live on the banks of the Sepik river - the Manambu and the Iatmul, and those who live off the Sepik River, or "Jungle dwellers" - the Yalaku and the Abelam-Wosera. The Gala may be considered an intermediate group. Their only village, called Swakap (or Swagup), is located off the April river (a tributary of the Sepik river) on a small watercourse connected to a lagoon. The Gala are reported to have had large war canoes in the twentieth century, like the neighbouring River dwellers. Similar to Jungle dwellers, they produce pottery. In the past, they must have occupied larger areas close to the current location of the Kwoma around the Ambunti mountain, from which they were dispersed as a result of the Gala wars (see Newton, 1971, and a summary and references in Aikhenvald, 2008: 16, 592-593).

Neighbouring people, with whom the Manambu are in contact and whose languages are not demonstrably related to those of the Ndu family, include Kwoma-Nukuma, Yessan-Mayo, Chambri, and Yerakai; all of them live off the Sepik River.

River dwellers and Jungle dwellers differ in their ways of life and subsistence. River dwellers live along the banks of the Sepik River and practice fishing - essentially a women's task - and some hunting (a men's job). Fish is their main trade object. They have a good knowledge of canoes and navigation.

In contrast, Jungle dwellers' villages are located off the Sepik River. Their inhabitants have less knowledge of canoes and river travel than those who live on the banks of the Sepik river. Jungle dwellers practice hunting and a little fishing, and make pottery. They produce sago which they trade for fish with River dwellers at traditional barter markets (see extensive discussion by Schindlbeck, 1980, and also Gewertz, 1983: 17-52). Garden produce is an important part of subsistence for both groups.

The differences in habits and lifestyle between River dwellers and Jungle dwellers are highlighted in a colourful account published by Staalsen (1965: 187). A River dwelling Western Iatmul (or Naura) from the village of Brugnowi (located close to the Manambu-speaking area) admonishes the Jungle-dwelling Yessan-Mayo for having no knowledge of paddles and canoes, no "breech clouts or grass skirts", and for their lack of ability "to learn" from the River-dwelling Naura. This reflects, in a nutshell, the general attitude of superiority and arrogance of River dwellers with regard to those groups who live off-river (some examples are given in Gewertz, 1983: 19; see also Aikhenvald, 2009: 14). In contrast, as far as I could judge, the Jungle dwellers do not consider themselves inferior in any way, just different.

Traditionally, relations between River dwellers and Jungle dwellers have been uneasy, to say the least. There are numerous accounts of military incursions by River dwellers on Jungle dwellers (see Gewertz, 1983: 29; Staalsen, 1965; Harrison, 1993), and of armed conflicts between the Manambu, the Gala, the Kwoma and a number of unidentified Jungle dweller groups (see Aikhenvald, 2009: 19-20). Many of those have resulted in the absorption of survivors by the Manambu majority. For instance, as a consequence of the Gala wars some of the Gala were absorbed into the Vali:k subclan of the Manambu - this is the basis of one of the iconic traditional narratives by the Manambu (see Harrison, 1993 and Aikhenvald, 2008: 636-651 and 2009). In all likelihood, the substrata from languages of the absorbed minorities account for significant grammatical differences between Manambu and other languages of the Ndu family.

At the same time, the River dwellers and the Jungle dwellers are in a symbiotic relationship of mutual dependency: the former group supplies the fish and the latter supply the sago, which is the major staple for everyone (see Gewertz, 1983: 3140; and Aikhenvald, 2009: 47-49 for an analogy from north-west Amazonia). The people have little if any knowledge of each other's languages. Traditionally, the produce used to be exchanged at socalled "silent" barter markets where women - the major players at markets - display their goods and accept - or not - other women's goods without using spoken language while bargaining. At present, with the spread of Tok Pisin, one of the official languages and a major lingua franca of PNG, trade and exchange are conducted in Tok Pisin. 
The differences between River dwellers and Jungle dwellers can be aptly described using Bateson's (1935: 181) category of "complementary differentiation", with elements of what he refers to as a "reciprocal" pattern of interaction.

We now turn to the differences in the overall linguistic situation, language attitudes, and languages of two neighbouring groups in interaction: the River-dwelling Manambu and the Jungle-dwelling Yalaku.

\section{The Manambu and the Yalaku close up}

We start with the Manambu and their language, and then turn to the Yalaku.

The Manambu language is spoken by about 3000 people in five villages, of which Avatip is by far the largest. The other major traditional village is Malu, the locus of the first encounters with early German explorers, located close to Ambunti; a smaller village called Apa:n is an offshoot of Malu. Dialectal differences between Avatip and Malu are very minor (see Aikhenvald, 2008: 620621). When the Sepik river changed its course in the mid-nineteen eighties, most of the Avatip people moved from a place called Yentchangai to the present location of the village (Harrison, 1990: 13; and plate 1 in Aikhenvald, 2008); some stayed behind and formed the Yawabak village.

The westernmost Manambu-speaking village, Yambon (or Yuanab), was established relatively recently, but prior to the arrival of Europeans (Claas, 2007). Bragge (1990) and Staalsen (1965) relate stories about how Yuanab had been settled by Jungle dwellers and people from the mountains - some from the Yerakai area, some from around the Gala-speaking Swakap - who had adopted Manambu as their language. The exact timing of this is unclear - Bragge's (1990: 40) estimate that this may have occurred around 1830 is hard to confirm, or to refute. The Yuanab people speak the most divergent variety of Manambu, perhaps due to the influence of varied and mostly unidentifiable substrata. At least some speakers in Avatip look down upon the Yuanab people. There are also a few closely-knit diasporic communities of the Manambu in Port Moresby, Lae, and Wewak (Aikhenvald, 2008: 1). A comprehensive grammar of Manambu is in Aikhenvald (2008); there is also a preliminary dictionary (Aikhenvald and Laki, 2013), and a collection of texts. A sIL team, Marva and Robin Farnsworth, worked in the area starting from 1963 and produced a Bible translation mostly based on the Yuanab variety which is not used; the translation is currently being revised by Ken Nayau, from Avatip.

The Yalaku language is spoken by about 300 people in the village of Yalaku. It is located in a mountainous region off the Sepik river in the vi- cinity of the lakes (as shown on the map). Slightly different (but mutually intelligible) dialects are spoken by c. 300 people in each of Kumajuwi and Hambukaini, located further off the River. (These are not shown on the map because of the lack of precise GPS coordinates.)

The original name of the village and the autodenomination of the people is Yelahambura. The name Yalaku is said to have been bestowed on the people by Väkinap, an important orator and the Luluai of Avatip (that is, a local chief appointed by colonial administration). According to a story told by Joel Ukaia (the current village councillor), Väkinap was instrumental in joining the forces of the Avatip and the Yalaku in their efforts to help the allies fight Japanese invaders during the second world war. After the war, the white colonial administrators and Väkinap offered the Yalaku protection from raids of neighbouring peoples, and made the name "Yalaku" the official name of the village. The exonym Kaunga (or Kawoga) is used by the Kwoma (in addition to a number of other alternative names, including Habora and Wan Sobo: see Bowden, 1997: xxIII). The Yalaku language has never been previously described. It was called "Yelogu" by Laycock (1965: 139-143), in a cursory grammar sketch based on the data obtained

"in the course of a single evening and the following morning, particularly from a young and not very intelligent informant named Avareka." [The reference is to the late Ambareka, a respectable elder in the community.]

The members of the community rejected "Yelogu" as a distortion of "Yalaku", based on an error of hearing. A preliminary phonological description was done by the sIl (Nayau n/d) (however, a translation project never got off the ground). Based on the author's fieldwork (2013-present), there is now an on-going dictionary project, a story-book and a grammar in preparation. Invaluable information on Yalaku ethnic history and their contacts with the neighbouring Kwoma comes from Bowden (1997: XX-XXIII). The existence of other Yalaku-speaking villages (such as the putative Kayukwa: Bowden, 1997: XXIII) has not been confirmed.

Typically for River dwellers, the Manambu supply fish while the Jungle-dwelling Yalaku supply sago. The Yalaku have some knowledge of canoes and travel along the lakes, but less so than the River dwellers. I was told that traditionally they used only roughly made rafts. Back in the old days, Yalaku women had no knowledge of grass skirts, similarly to some of their Kwoma neighbours (as documented by Behrmann, 1922 during the ethnographic expedition in 1912). This resonates with Staalsen's (1965) account of Jungle dwellers quoted above. According to Kwariag, a highly knowledgeable female story-teller from the Yalaku village, women used to go around naked, 
and if strangers arrived, wrapped themselves in large string-bags, moving sideways, so as not to show their genitalia.

The ways in which the Manambu and the Yalaku refer to each other deserve a mention.

In the Manambu terminology, the word for River dwellers (ñaba-du (Sepik.River+LINKER-man), literally men of the Sepik River), covers the Manambu and the Iatmul. These are distinct from dry-land dwellers, called neb-e-du (dry.landLINKER-man) which corresponds to the notion of Jungle dwellers. This is also used as a derogatory term with a meaning of "hillbilly", often directed by annoyed mothers at unruly and misbehaving children. People who live off the Sepik river are also called kwareb-a-du (jungle/bush-LINKER man) "jungle man".

The Yalaku refer to themselves as nubu-du (mountain-people) "people of the mountain" or saikopa-du (low.lying.bush-man) "people of the low lying bush". These terms are not extended to any of their neighbours. The Kwoma and the Nukuma are referred to in Yalaku as TSabwi. (This term has no other meaning.)

The general term Kwalap in Yalaku covers all the peoples who live along the Sepik River and beyond it, subsuming both River dwellers - such as the Manambu and the Iatmul - and numerous Jungle dwellers, including the Yessan-Mayo, Gala, Wogamusin, Tsenapian, and many more. The people of Avatip are alternatively referred to as Yentchangai (the name of the former location of Avatip).

The use of the term Kwalap by the Yalaku with reference to most non-Yalaku people is puzzling. The name Kwalap - together with its song-style counterpart Geñap - is employed in Manambu as an address term for members of the Yimal clan (part of the Gla:gw clan group, associated with the jungle and everything dark). According to the Manambu lore, a group called Geñap-Kwalap was defeated by the Manambu of Avatip (Aikhenvald, 2009; according to Harrison's, 1993: 67 estimate, this may have happened at the end of the nineteenth century). We know nothing about the Geñap-Kwalap; but since this name is used as a term of address for members of the "Dark" clan associated with the jungle, they may have been Jungle rather than River dwellers.

Each subclan of the River-dwelling Manambu used to have established preferential trade partners, many of them Jungle dwellers. The Yalaku used to be the preferential trade partners of the Yalaku-Gabak subclan of the Gla:gw clan (see Table 1 in Aikhenvald, 2009; and also Harrison, 1990: 70-73). (I was assured by Avatip elders that the name Yalaku-Gabak of one of the Manambu sub-clans had nothing to do with the name "Yalaku".) The Kwoma were preferential partners of the Sarak subclan of the Wulwi-Nawi clan group.

Trade relationships between the Manambu and the Yalaku continue at present. The Yalaku reg- ularly bring their sago to sell in Avatip, the closest Manambu village. Sago is now being sold for money rather than being exchanged for fish. In May 2013, as we were approaching the Avatip village, our canoe arrived at the same time as a canoe full of sago brought for sale by two young girls from the Yalaku village. This was my very first encounter with Yalaku speakers, and the start of my fieldwork.

We now turn to the linguistic situation, language attitude, and language use among the Manambu and the Yalaku.

\section{Multilingualism, language attitudes, and language use: Manambu and Yalaku in contrast}

The Manambu and the Yalaku differ from each other in terms of language knowledge and patterns of multilingualism, language attitudes, and language preservation.

Generally, the River dwellers and the Jungle dwellers tend to display different patterns of multilingualism and knowledge of each others' languages. Since the River dwellers consider themselves "superior" to the Jungle dwellers, they tend not to learn Jungle dwellers' languages (equating them with cries of birds of paradise feeding on a branch: $c f$. Harrison, 1993: 40). Trade between the Manambu and groups of Jungle dwellers appears to have involved limited Manambu-dominated pidgins ( $c f$. Harrison, 1993: 40; also see Bowden, 1997); nowadays it is conducted using Tok Pisin.

The River dwellers and the Jungle dwellers tend not to live together in one multilingual village. In contrast, Jungle dwellers frequently form rather stable alliances and different allied groups used to live together in one village, promoting multilingualism in each other's languages (see Aikhenvald, 2009: 65 and references there). The Yalaku and the Kwoma are a case in point. At least a third of the Yalaku people have good competence in Kwoma. In contrast, there is hardly any Manambu-Kwoma multilingualism (despite a long-term interaction between the two groups, and even the existence of a putative Manambu-Kwoma pidgin described by Bowden, 1997).

Incipient bilingualism between Yalaku and Manambu is a new phenomenon, developed due to the school system. During the past decade, the Avatip Primary School has been attracting students from all over the Ambunti region. As a consequence, a few inhabitants of the Yalaku village who had studied there understand and even speak Manambu. The expansion of unilateral knowledge of Manambu by the Yalaku is a straightforward outcome of the newly established schooling system.

What sets Yalaku apart from Manambu and other $\mathrm{Ndu}$ languages is a strong impact from Kwoma, an unrelated language. Kwoma - spoken 
by the people who live off the Sepik river - is a member of the small Kwoma-Nukuma family, not demonstrably related to the Ndu languages (see Aikhenvald, 2009 for a discussion). The Yalaku-Kwoma bilingualism goes back several generations (Bowden, 1997: XXII-XXIII). Due to a history of interactions with the Kwoma-speaking people of Tongwinjamb and Bangwis (Bowden, 1997: XXII-XXIII), Yalaku has undergone contact induced changes in its grammar and has incorporated numerous borrowings and grammatical calques from Kwoma. The Kwoma impact on Yalaku can be seen in numerous loans, e.g. Kwoma iñaka, Yalaku wuñaka "mind, state of mind"; Kwoma hadebas "fine, nice", Yalaku hadepas "nice"; Kwoma awo, Yalaku au "traditional frying pan"; Kwoma arowa "to attack", Yalaku yaregwa "to attack, to kill"; Kwoma hi, Yalaku yi "name" and the greeting apo "hello, good-bye" shared by the Kwoma and the Yalaku. Grammatical patterns shared by Kwoma and Yalaku, and not found in Manambu or other Ndu languages include the ways of framing speech reports, the system of case marking depending on whether the referent is topical or not, and repetition of verbal roots used for intensifying an action (see Kooyers, 1974; and a summary in Aikhenvald, 2015).

There are no monolingual speakers of either Manambu or Yalaku, as children grow up learning Tok Pisin at an early age. The use of Tok Pisin has drastically increased over the past two decades: Tok Pisin, in addition to Papua New Guinea English, is the main language used at school (including the elementary school in Yalaku and the Avatip Primary School), at village meetings in Avatip and in Yalaku, and also at joint meetings and assemblies which bring together people from various Middle Sepik communities.

Manambu and Yalaku differ in terms of language vitality. Both languages continue being learnt by children, albeit in a somewhat impoverished form. Traditional song genres have been all but lost by both Manambu and Yalaku. In Avatip, most children no longer know the traditional terms associated with ritual and totemic structures, and even their own village names. A number of traditional ceremonial practices (such as the mortuary ritual Keketep, name debates and the yam harvest ritual) are still performed among the Manambu (Harrison, 1990; Aikhenvald, 2008: Chapter 1; 2010), despite the pervasive presence of a variety of Christian denominations. In contrast, the Yala$\mathrm{ku}$, strong Christians and members of the South Seas Evangelical Church of Pentecostal orientation, have abandoned most traditional ceremonial practices which nowadays are only remembered (the mourning ritual, called kaba re (lit. ghost sit), is the only one still performed). But knowing one's village name is a matter of course.

The influx of people from other villages of the East Sepik Province and other PNG provinces (in- cluding New Britain and the Highlands) is a factor which promotes increasing use of Tok Pisin in Avatip, to the detriment of Manambu. As a consequence, the Manambu of Avatip are acutely aware of an impending danger of language loss, blamed on outsiders, and partly on those who live outside the Manambu villages and do not teach the language to their children.

In contrast, the Yalaku do not see their language as immediately endangered. Most people in the village of Yalaku (with the exception of about half-a-dozen Kwoma women married into the village) speak the language. A few Yalaku families living outside the village in towns such as Maprik, Angoram and Wewak maintain close ties with the village and are not viewed as threatening the survival of the language in any way.

Manambu and Yalaku have been influenced by Tok Pisin in different ways. The impact of Tok Pisin on Manambu is rather substantial. Since I started my fieldwork with the Manambu in the 1990s, the number of Tok Pisin loans and code-switches in the language has increased exponentially (see also Aikhenvald, 2008: 605-618). Two examples from similar stories, recorded at different times, show the increase in Tok Pisin forms (in bold). Example (1) was recorded from a speaker in Avatip in 2013.

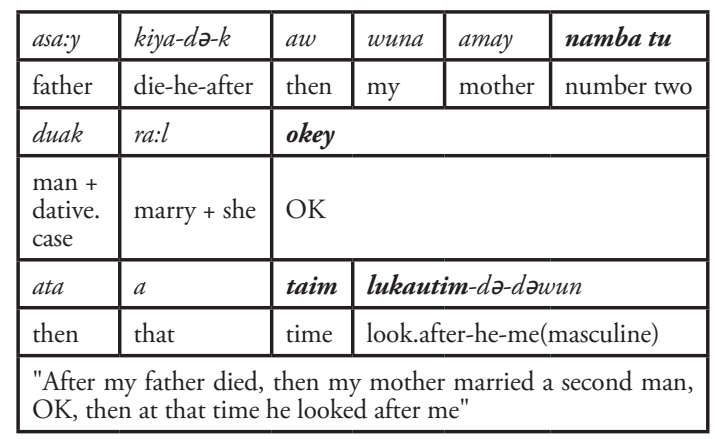

Example (2) recorded in 2001 (from a different speaker) shows no Tok Pisin forms:

\begin{tabular}{|l|l|l|l|l|}
\hline asa:y & kiya-də-k & aw & wuna & amay \\
\hline father & die-he-after & then & my & mother \\
\hline nəkə-də & duak & ra:l & ya:kya \\
\hline $\begin{array}{l}\text { another- } \\
\text { mascu- } \\
\text { line }\end{array}$ & $\begin{array}{l}\text { man }+ \\
\text { dative.case }\end{array}$ & $\begin{array}{l}\text { marry } \\
+ \text { she }\end{array}$ & all.right \\
\hline ata & $a$ & səkər & yakwiya-də-dəwun \\
\hline then & that & time & $\begin{array}{l}\text { look.after-he-me (mascu- } \\
\text { line) }\end{array}$ \\
\hline $\begin{array}{l}\text { "After my father died, then my mother married a second man, } \\
\text { all right, then at that time he looked after me" }\end{array}$ \\
\hline
\end{tabular}

Many of the Tok Pisin nouns and verbs are now regularly used by the Manambu speakers in any genre of discourse, including kamapim "come up", statim "start", lukautim "look after", les "lazy, unwilling", laikim "like", lewa "beloved", sop "soap", taim "time", and lain "family line, family". Even older female speakers - insecure in 
their Tok Pisin - employ them in their speech. Incidentally, this confirms their status as established loans rather than nonce "code-switches" from one language to another. Terms for number words higher than five are usually given in Tok Pisin (with the exception of some traditional texts relating head-hunting exploits). Many people use wanpela "one" as a number word and for introducing new participants in discourse, e.g. wanpela ta:kw (one:Tok.Pisin woman) "a woman, one woman". The Tok Pisin form nau "now"; a marker meaning "and then" is used very frequently after Manambu verbs in clause chains, and can now be considered a borrowed conjunction. The Tok Pisin discourse marker em nau "there! this is it" is now a feature of the language as spoken by all the generations. The English okey has all but replaced the Manambu ya:kya "OK, all right".

In contrast, lexical loans from Tok Pisin into Yalaku are scarce. Even terms for modern mobile technology are developed out of language-internal resources. For instance, the Manambu would use the Tok Pisin or English term flex for mobile credits (see King, 2014 on the Tok Pisin terminology for new concepts to do with technological advances). In contrast, the Yalaku employ the word wifa, originally meaning "a drum beat" or mesireba, originally "stick for beating a slit-gong drum", for the same object.

Notions associated with introduced goods are typically formed by adding a modifier "white, non-indigenous" to a term similar to the introduced object. The term for "non-indigenous" or "white" person in Yalaku is kaba whose other meaning is "ghost", or "spirit", e.g., kaba-takwa (spirit-woman) "a spirit woman, a female ghost (also used to refer to a white woman)", kaba-wapi (spirit-bird) "magic (sanguma) bird (who brings a disaster)". Some of the Yalaku terms containing kaba are polysemous: for instance, kaba-mi (spirit-wood) can be used to refer to a guitar or a mobile phone (the meanings can be easily disambiguated by the context).

The Yalaku formations with kaba which correspond to loanwords in Manambu include $k a$ ba-asa (spirit-dog) "pussy cat", $c f$. Manambu pusi (from Tok Pisin pusi); Yalaku kaba hokga (spirit tuft.of.grass) "steelwool" (for cleaning dishes), Manambu stilwul (from English steel wool); Yalaku kaba-mut Ja (spirit-aran.fruit) "pineapple", Manambu painepol "pineapple" (from English pineapple). Recently, a number of Yalaku speakers have been trying to change the terms referring to "white peoples" good's from kaba to wama "white", saying that kaba is "not good". The word $k a b a$ in Yalaku is a borrowing from Kwoma gaba (found in Bowden, 1997: 42-43) which has a similar range of meanings - "ghost, soul" and "European". The Kwoma form gaba is found in expressions very similar to those in Yalaku, e.g. gaba asa "cat" (lit. the ghost's dog), or gaba veyi "car" (lit. the ghost's canoe). The form kaba-in Manambu occurs only in kaba-sek (?-seed) "rice". It is not a cognate to Yalaku kaba because a word-initial $k$ in Manambu regularly corresponds to Yalaku $h$ (e.g. Manambu kam, Yalaku hama "breadfruit"), and may well be a loan from Kwoma.

In the instances when Manambu redeploys an indigenous term to cover an introduced entity, the forms used are markedly different from those in Yalaku. The term for non-indigenous people in Manambu is wali, lit. east wind (see Harrison, 1990: 12, 43-44 and Aikhenvald, 2008: 11, for the totemic association between the "east wind", areas to the east of the Manambu regions and the Wulwi-Nawi clan group associated with sun, moon and white and shiny objects). The Manambu term for "money" is sa:n "shell valuable", or kabak "stone" (referring to a large amount of money), while the Yalaku term is kaba-yuwa (spirit bride-price/shell valuable).The Manambu name for a watch is taba-ñe (hand-sun), and the Yalaku form is nugwa hats (sun part/area). The Manambu call alcohol wali-gu (white.person-water) or kuprape gu (bad water), while the Yalaku refer to it as $k a b a-g u$ (spirit-water).

Tok Pisin forms are only used if no comparable concept in Yalaku is available, filling a "gap" in the language (this is what Clark, 1982 refers to as a "necessary borrowing"). Yalaku has no lexemes to do with winning, exceeding someone and competition in general (neither does the language have a comparative or a superlative construction: see Aikhenvald, forthcoming). Dixon (2008: 814) offers a societal explanation for this. As he puts it,

"small tribes with an egalitarian social system and item-for-item trade do not generally indulge in competition; they often lack words for 'compete', 'win', 'lose' and 'beat' (as in a game). Such concepts are tied in with comparison [...]. Groups of this type have little use for the idea of 'more than' or 'less than'."

This is in contrast to Manambu which does have a comparative construction and two verbs with comparative meanings: kakel- "compete" and yi"go, exceed". (The verb yi- "go" in Yalaku does not have the meaning of "exceed".) In Yalaku narratives and conversations about beating someone in a battle, one just uses the various verbs for "kill" and "beat up". The lack of focus on competition and "winning" among the Yalaku was brought home to me by one of the speaker's comment on how the Manambu people are fixed on competing with everyone and exceeding others, and the Yalaku people are not. When talking about this, he used the Tok Pisin verb winim "surpass, get ahead of someone" - there was no other means available in Yalaku for the foreign concept.

A Tok Pisin term can be used in Yalaku to make the expression more compact, or simpler. In contrast to Manambu, there is no verb "have" in Yala- 
$\mathrm{ku}$. The most common way of expressing possession in the traditional language is by saying "be with something". This is illustrated in example (3).

\begin{tabular}{|l|l|l|}
\hline apatepa & poko-way & wuni=te \\
\hline many & thing-WITH & 1 sg=be \\
\hline \multicolumn{2}{|l|}{ "I have many things" (lit. I am with many things) } \\
\hline
\end{tabular}

The Tok Pisin verb gat "have, be" (accompanied by the Tok Pisin predicate marker $i$ ) and its negative counterpart $i$ no gat is occasionally used. In her passionate speech in church, a prominent Yalaku woman was trying to convince the congregation to share some food with communities living on the river banks and affected by the floods, saying example (4).

\begin{tabular}{|l|l|l|l|l|l|}
\hline ñani & igat & $\begin{array}{l}\text { ha } \\
-b o k o,\end{array}$ & tfi & i no gat & ha-boko \\
\hline we & $\begin{array}{l}\text { have. } \\
\text { TOK. } \\
\text { PISIN }\end{array}$ & $\begin{array}{l}\text { eat- } \\
\text { thing }\end{array}$ & they & $\begin{array}{l}\text { have. } \\
\text { not. } \\
\text { TOK. } \\
\text { PISIN }\end{array}$ & eat-thing \\
\hline
\end{tabular}

"We have food, they (people who live on the river banks) do not have food."

Tok Pisin number words for quantities more than twenty are used by everyone - this is unlike Manambu whose speakers employ Tok Pisin numbers from five onwards, and even from one to four. It is as if lexical loans from Tok Pisin were intentionally avoided, in order to preserve the position of Yalaku as an in-group language for its small community of speakers, much like a secret language (tok-hait, in Tok Pisin). This attitude is reminiscent of a cultural inhibition against recognizably foreign items. The ensuing linguistic purism provides a mechanism for stopping an influx of borrowed lexical forms (see the discussion in Aikhenvald, 2006: 39-40, with special attention to northwest Amazonia, and a case study of the Arizona Tewa by Kroskrity, 1993). As Thurston (1987: 93) put it,

"since people generally construe languages as being collections of words, it is primarily by lexical form that linguistic groups identify linguistic contrasts among themselves."

But such an inhibition against borrowings may not extend to grammatical forms.

A rather striking instance of a borrowed morpheme in Yalaku is the Tok Pisin negator no "no" with non-verbal predicates and in copula clauses. Yalaku has a highly complex system of marking negation with a combination of prefixes, suffixes and independent words depending on tense, aspect, modality, mood and type of predicate. A Tok Pisin all-purpose negative particle is simpler - this could be an explanation for its use, illustrated in example (5).

\begin{tabular}{|l|l|l|l|}
\hline$t e$ & $n o$ & $p a k a=t e$ & $t e$ \\
\hline he & no.TOK.PISIN & for.nothing=he & stay \\
\hline \multicolumn{4}{|l}{ "He wasn't doing nothing' (lit. he did not stay (for) nothing)." } \\
\hline
\end{tabular}

Such examples are very frequent in spontaneous, unplanned narratives and in conversations. When speakers are made aware of them, they consider them slips of the tongue. (5) was corrected as (6) (as we were transcribing a recorded story where the sentence appeared).

\begin{tabular}{|l|l|l|l|}
\hline te & paka & hebu & te-t \\
\hline he & for.nothing & $\begin{array}{l}\text { NEGATIVE(used. } \\
\text { in.statements) }\end{array}$ & stay-NEGATIVE \\
\hline \multicolumn{4}{|l}{ "He wasn't doing nothing" (litt. "he did not stay (for) nothing"). } \\
\hline
\end{tabular}

Thanks to the pervasive Kwoma-Yalaku bilingualism, Yalaku story-tellers often switch into Kwoma. Examples recorded include Kwoma neja instead of Yalaku yanan "grandchild" and Kwoma hama instead of Yalaku kuse "finish". This is a feature of the speech of men who have Kwoma spouses or close relatives.

The lexicons of Manambu and of Yalaku differ in further ways. The lack of lexemes to do with winning or competing in Yalaku was mentioned above. The Manambu specialize in fishing (both in the Sepik river and in the surrounding lakes). Yalaku do little fishing, limited to the lakes. As a consequence, it has been possible to record more than two dozen names for native fish in Manambu, and only eleven for Yalaku. In contrast, Yalaku has half-a-dozen special terms for the shade of soil colour (typical for their habitat), none of which have a Manambu equivalent. A striking feature of the Manambu lexicon is multiple synonymy for numerous culturally important items, whereby different names for different objects are owned by a particular subclan (in addition to a general term which is used by the whole community; Aikhenvald and Luma Laki, 2013 contains a few examples; see also Aikhenvald, 2018). This is absent from Yalaku. Among the Manambu, the knowledge of these terms is on the wane $-\mathrm{a}$ fact lamented by older people.

\section{The Manambu and the Yalaku in the modern world: to conclude}

The Manambu and the Yalaku are neighbours. They speak closely related but not mutually intelligible languages. The two groups share the spoils of European influence - European food and clothing, and the school system. The traditional differences between them remain, albeit in a somewhat different guise.

In the past there may have been more cultural differences between the Manambu and the Yalaku. Presently, there are no carvers among either $\mathrm{Ma}-$ nambu or Yalaku. But things may have been different in the past. According to Ross Bowden (p.c.), the Yalaku have never specialised in carvings. A de- 
scription of the Manambu carvings (all stemming from Yambon, or Yuanab) is in Craig (2015).

The two groups belong to distinct cultural divisions - the Manambu are traditional River dwellers and the Yalaku are traditional Jungle dwellers, or "dry-land people". But the traditional corollaries of this division - to do with subsistence activities, exchange patterns and the lack of balanced multilingualism - are still there. So are the elements of "complementary differentiation" (using Bateson's, 1935: 181 term).

The two groups are acutely aware of each other's differences. There are no traces of hostility between them (note that warfare in the Middle Sepik was brought to an end by the Australian administration starting from the 1920s: see, for instance, Aikhenvald, 2009; Harrison, 1993). A somewhat condescending attitude of the River dwellers towards the Jungle dwellers is still reflected in the derogatory overtones of the term "dryland people" by the Manambu. On the other hand, the Yalaku express some resentment against the high competitiveness of River dwellers, especially the Manambu.

Reciprocal relationships between the two groups with their complementary expertise - fishing for the River-dwelling Manambu, sago production for the Jungle-dwelling Yalaku - continue. However, the barter markets are no longer "silent", as the two groups share a lingua franca, Tok Pisin, used for conducting transactions. In addition, the Yalaku frequently go to Avatip to sell sago, where they use Tok Pisin as a language of interaction.

The dynamics of competence in each other's languages has changed. Yalaku children attend the Avatip Primary School, and acquire at least some competence in Manambu. In contrast, the Manambu do not learn Yalaku. The traditional Yalaku-Kwoma bilingualism - established due to stable alliances between the Kwoma and the Yala$\mathrm{ku}-$ continues to thrive. The fact that the village of Yalaku now belongs to the same administrative division (ward) as the Kwoma-speaking community of Bangwis contributes to this alliance. Much of the administrative business is conducted in Kwoma. There are numerous loans from Kwoma into Yalaku, and speakers may switch between the two languages. However, switching between Tok Pisin and Yalaku, and incorporating Tok Pisin loans, is carefully avoided - in all likelihood, due to a desire to keep Yalaku as unintelligible to its closest neighbours as possible. In contrast, code-switching with Tok Pisin and Tok Pisin loans are prominent in present-day Manambu.

Avatip is open to outsiders; as a result, more and more people in the village do not speak Manambu and resort to Tok Pisin. The impending language loss is a matter of concern for the traditional speakers. This is in contrast to Yalaku where most people speak the language and can be con- sidered balanced bilinguals (Yalaku-Tok Pisin) or trilinguals (adding Kwoma to this).

Despite the levelling of some traditional differences, the Manambu and the Yalaku speech communities remain very different in their responses to social and cultural changes as reflected in their linguistic change and linguistic practices.

\section{Acknowledgements}

I am grateful to my teachers of Manambu, especially Pauline Yuaneng Agnes Luma Laki, Jacklyn Yuamali Benji Ala and James Sesu Laki, and my teachers of Yalaku, especially Joel Ukaia, David Kwaibori, Yafa Mark, Yafa Solomon, Elsa Kasindimi and Ritha Suan, and to Thomas Yati, for helping me understand a bit of Kwoma. Thanks go to R.M.W. Dixon, Borut Telban and the editors for critical comments, to Ross Bowden for answering my questions about the Kwoma, and to Brigitta Flick for checking the manuscript.

\section{REFERENCES}

Aikhenvald Alexandra Y., 2004. Language endangerment in the Sepik area of Papua New Guinea, in O. Sakiyama and F. Endo (eds), Lectures on endangered languages: 5 - From Tokyo and Kyoto Conferences 2002, The project "Endangered languages of the Pacific Rim", Suita, Osaka, pp. 97-142.

—, 2006. Grammars in contact: a cross-linguistic perspective, in A.Y. Aikhenvald and R.M.W. Dixon (eds), Grammars in contact: a cross-linguistic typology, Oxford, Oxford University Press, pp. 1-66.

-, 2008. The Manambu language of East Sepik, Papua New Guinea. Oxford, Oxford University Press.

—, 2009 [dated 2008]. Language contact along the Sepik River, Anthropological Linguistics 50, pp. 1-66.

—, 2010. The social life of a language: will Manambu survive?, in Fl. Farfán, J. Antonio and F. Ramallo (eds), New Perspectives on Endangered Languages. Bridging gaps between sociolinguistics, documentation and language revitalization, Amsterdam, John Benjamins, pp. 13-28.

—, 2015. Differential case in Yalaku, Oceanic Linguistics 54, pp. 241-70.

—, 2018. The magic of names: a fieldworker's view, in H. S. Sarvasy and D. Forker (eds), Word hunters, Amsterdam, John Benjamins, pp. 9-27. 
-, Forthcoming. Comparison, contrast and similarity in Yalaku, in Linguistic Discovery.

Aikhenvald Alexandra Y. and Pauline Agnes Yuaneng LUMA LAKI, 2013. Materials for a preliminary dictionary of the Manambu language, Community materials for the Avatip Primary School.

Bateson Gregory, 1935. Culture contact and schismogenesis, Man 35, pp. 178-83.

Behrmann Walter, 1922. Im Stromgebiet des Sepik, Berlin, August Scherl.

Bowden Ross, 1997. A Dictionary of Kwoma, a Papuan Language of North-east New Guinea, Canberra, Pacific Linguistics.

BRAGGE Laurie, 1990. The Japandai migrations, in N. Lutkehaus, C. Kaufmann, W. E. Mitchell, D. Newton, L. Osmundsen and M. Schuster (eds), Sepik Heritage. Tradition and Change in Papua New Guinea, Durham, Carolina Academic Press, pp. 36-49.

ClaAs Ulrike, 2007. Das Land entlang des Sepik. Vergangenheitsdarstellungen und Migrationsgeschichte im Gebiet des mittleren Sepik, Papua New Guinea, Berlin, LIT-Verlag, Göttinger Studies zur Ethnologie 17.

Clark Ross, 1982. "Necessary" and "unnecessary" borrowing, in A. Halim, L. Carrington and S. A. Wurm (eds), Papers from the Third International Conference on Austronesian Linguistics, Vol. 3: Accent on variety, Canberra, Pacific Linguistics, pp. 137-43.

Craig Barry, 2015. Middle Sepik Manambu, in B. Craig, R. Vanderwal and C. Winter (eds), War trophies or curios?, Melbourne, Museum Victoria Publishing, pp. 91-105.

Dixon R.M.W., 2008. Comparative constructions. A cross-linguistic typology, Studies in Language 32, pp. 787-817.

Foley William A., 1986. The Papuan languages of New Guinea, Cambridge, Cambridge University Press.

—, 1988. Language birth: the processes of pidginisation and creolisation, in F. J. Newmeyer (ed.), Language: The socio-cultural survey, Vol. IV of Linguistics: The Cambridge Survey, Cambridge, Cambridge University Press, pp. 162-84.

Freudenburg Allen, 1976. The dialects of Boiken, in R. Loving (ed.), Surveys in five Papua New Guinea languages, Ukarumpa, Summer Institute of Linguistics, pp. 80-90.
Gewertz Deborah B., 1983. Sepik River societies. A historical ethnography of the Chambri and their neighbors, New Haven, Yale University Press.

Harrison Simon J., 1990. Stealing Peoplés Names. History and Politics in a Sepik River Cosmology, Cambridge, Cambridge University Press.

-, 1993. The mask of war. Violence, ritual and the self in Melanesia, Manchester, Manchester University Press.

JendRASCHEK Gerd, 2012. A grammar of Iatmul, Habilitationsschrift, University of Regensburg.

KING Phil, 2014. Tok Pisin and Mobail Teknoloji, Language and Linguistics in Melanesia 34, pp. 118-52.

KoOYers Orneal, 1974. Washkuk grammar sketch, Workpapers in Papua New Guinea Languages 6, pp. 5-74.

Kroskrity Paul V., 1993. Language, history and identity: ethnolinguistic studies of the Arizona Tewa, Tucson, The University of Arizona Press.

LaYcock Donald C., 1965. The Ndu language family (Sepik District, New Guinea), Canberra, Linguistic Circle of Canberra Publications.

NaYau Ken (n.d.). Organized phonology data. Yalaku, siL, Ukarumpa.

Newton Douglas, 1971. The Crocodile and the cassowary: Religious Art of the Upper Sepik River, New Guinea, New York, Museum of Primitive Art.

SAPIR Edward, 1929. The status of linguistics as a science, Language 5, pp. 207-214.

Schindlbeck Markus, 1980. Sago bei den Sawos, Basel, Ethnologisches Seminar der Universität und Museum für Völkerkunde, Basler Beiträge zur Ethnologie 19.

StaAlsen Phil, 1965. Brugnowi origins: the founding of a village, Man 65, pp. 184-188.

Thurston William R., 1987. Processes of change in the languages of north-western New Britain, Canberra, Pacific Linguistics.

Wendel Thomas D., 1993. A preliminary grammar of Hanga Hundi, MA thesis, University of Texas at Arlington.

WiLson Patricia, 1976. Ambulas dialect survey, in R. Loving (ed.), Surveys in five Papua New Guinea languages. Workpapers in Papua New Guinea languages 16, Ukarumpa, Summer Institute of Linguistics, pp. 51-79. 